\title{
Impact of Technical Training in Modern Gadgets for Professionals
}

\author{
W.Porselvi, K.Thiyagarajan, S. Janifer Vinnarasi
}

\begin{abstract}
Shopper steadfastness can as often as possible be seen as a key differentiator and it has logically become a key segment of the business strategy. Here the people from the Madras Management Association (MMA) are its customers. People are the people who buy the organizations gave by the affiliations, endeavors affiliations, associations as people's satisfaction towards the alliance's organizations are concentrated to evaluate the introduction level of MMA. Satisfaction to be the delight gotten by someone from the use of items or organizations offered by another person or social affair of people or the state of being content with a condition.. A customer can be a buyer, yet a customer may not so much be a customer. People ecstasy, which means that satisfaction, is and has reliably been the most central thing for the connection. Different studies have demonstrated that the whole deal accomplishment of an organization is immovably related to its ability to make and keep up unflinching and satisfied customers, conform to customer needs and developing tendencies. To screen buyer faithfulness, and to make a move for improving it, different systems have been made and attempted. Shopper dedication expect a huge activity inside your business. Not only is it the primary marker to check customer commitment, perceive down and out customers, lessen mix and augmentation pay; it is moreover a key reason for partition that makes you pull in new customers in forceful business conditions. Part satisfaction is the general impression of people about the supplier and organizations passed on by the supplier.
\end{abstract}

Key words: Association, Customers satisfaction, promotion, expectations, communication

\section{INTRODUCTION}

Since the mid-1990s, there has been a basic move in dealing with a record transport toward using self-advantage channels, for instance, web keeping cash. In the midst of the past a significant extended period of time, online dealing with a record affirmation has been quick and current around the globe. Around $74 \%$ of the private keeping cash customers in Finland are standard customers of web dealing with a record benefits[1]-[5]

\section{SCOPE OF THE STUDY}

The study on member's association with MMA \& its impact on their professional life would enable the association to understand how the perception of members is towards the

Revised Manuscript Received on December 30, 2019.

W.Porselvi, Assistant Professor, Department Of Science and Humanities,Bharath Institution Of Higher Education And Research Tamilnadu India Email: porselviwilson@gmail.com

K.Thiyagarajan, Assistant Professor, Department Of Science and Humanities,Bharath Institution Of Higher Education And Research amilnadu India Email: thiyagu768@gmail.com

T. S. Janifer Vinnarasi Assistant Professor, Department Of Science and Humanities,Bharath Institution Of Higher Education And Research. amilnadu India Email: mjjaa24@gmail.com
MMA.MMA would come to know the level of satisfaction among its membersand would be able to discover the unmet expectations of the members. Through this study the association is in a position to find out which mode a program is highly effective \& beneficial based on which the association can focus on its execution methods and make some required improvements or continue with its present execution methods in an effective manner.[6]-[10]

\section{NEED FOR THE STUDY}

The customer satisfaction, expectation \& their perception towards the organization is very much essential for the success of any organization. The study is needed to understand how the association's performance is leaving an impact on its members. The study is also needed to discover which mode of association's activities emerges to be more beneficial to the association and proves to be more effective for members. The study would also enable the association to understand its member's responsiveness towards alternative communication modes.[11]-[15]

\section{OBJECTIVES OF THE STUDY}

\section{A. Primary Objective:}

To study Member's association with MMA \& its impact on their professional life.

\section{B. Secondary Objective:}

(i) To find out the nature and purpose of taking membership in MMA

(ii) To study the effectiveness of managerial activities conducted by the MMA

(iii) To analyze member satisfaction towards benefits derived by them through membership

(iv)To find out the mode of communication $\&$ promotion of association's programmes.

(v)To find out the member's growth \& expectations through availing a membership in association.

\section{RESEARCH METHODOLOGY}

Research theory is an investigation of thinking about how research is to be finished. Obvious research can be explained as a declaration of issues as they are at present personality hthe examiner having no control over factor. In its essence edifying examinations are used to depict various pieces of the wonder.

Published By: 
Connecting with assessment is used to delineate characteristics or possibly lead of test people.

It is made arrangements for lighting up current issues or issues or situation through a strategy of data assembling that engages them to delineate the condition more absolutely than was possible without using this system. A looking at technique is a procedure for picking test people from a masses. It is a strategy used in authentic examination in which a destined number of discernments are taken from a greater people. Discretionary examining is a methodology for testing from a masses wherein (a) the assurance of a model unit relies upon probability and (b) every part of the people has a known, non-zero probability of being picked.[16]-[20]

\section{RESULTS AND DISCUSSION}

\section{ONE WAY ANOVA}

$\mathbf{H}_{\mathbf{O}}=$ There is no significance between age of the respondents and hospitality quality.

$\mathbf{H}_{\mathbf{1}}$ There is significance between age of the respondents and hospitality quality.

\begin{tabular}{|c|c|c|c|c|c|c|c|c|}
\hline \multicolumn{9}{|l|}{$\begin{array}{l}\text { Descriptive } \\
\text { AGE }\end{array}$} \\
\hline \multirow{3}{*}{\multicolumn{2}{|c|}{$\mathrm{N}$}} & \multirow{3}{*}{$\begin{array}{l}\text { Mea } \\
\text { n }\end{array}$} & \multirow{3}{*}{$\begin{array}{l}\text { Std. } \\
\text { Deviati } \\
\text { on }\end{array}$} & \multirow{3}{*}{$\begin{array}{l}\text { Std. } \\
\text { Error }\end{array}$} & \multicolumn{3}{|c|}{$\begin{array}{l}95 \% \text { Confidence } \\
\text { Interval for Mean }\end{array}$} & \multirow{3}{*}{ Maxi } \\
\hline & & & & & Lower & Upper & Mini & \\
\hline & & & & & Bound & Bound & mum & \\
\hline LESS THAN & 16 & 1.000 & .00000 & .0000 & 1.0000 & 1.0000 & 1.00 & 1.00 \\
\hline 30 YEARS & & 0 & & 0 & & & & \\
\hline 31.40 & 52 & 1.615 & .49125 & .0681 & 1.4786 & 1.7521 & 1.00 & 2.00 \\
\hline YEARS & & 4 & & 2 & & & & \\
\hline 41.50 & 41 & 2.122 & 33129 & .0517 & 2.0174 & 2.2265 & 2.00 & 3.00 \\
\hline YEARS & & 0 & & 4 & & & & \\
\hline 51.60 & 6 & 3.333 & .51640 & .2108 & 2.7914 & 3.8753 & 3.00 & 4.00 \\
\hline YEARS & & 3 & & 2 & & & & \\
\hline 60 YEARS \& & 5 & 4.600 & .54772 & .2449 & 3.9199 & 5.2801 & 4.00 & 5.00 \\
\hline ABOVE & & 0 & & 5 & & & & \\
\hline Total & 120 & $\begin{array}{l}1.916 \\
7\end{array}$ & .85586 & $\begin{array}{l}.0781 \\
3\end{array}$ & 1.7620 & 2.0714 & 1.00 & 5.00 \\
\hline
\end{tabular}

\section{ANOVA}

\section{QUALITYOFHOSPITALITY}

\begin{tabular}{|c|c|c|c|c|c|}
\hline & $\begin{array}{l}\text { Sum } \\
\text { Squares }\end{array}$ & $\mathrm{df}$ & $\begin{array}{l}\text { Mean } \\
\text { Square }\end{array}$ & F & Sig. \\
\hline $\begin{array}{l}\text { Between } \\
\text { Groups }\end{array}$ & 67.935 & 4 & 16.984 & 101.561 & .000 \\
\hline Within Groups & 19.231 & 115 & .167 & & \\
\hline Total & 87.167 & 119 & & & \\
\hline
\end{tabular}

\section{RESULT:}

Table value of $F=30.293$. $5 \%$ level of significance in the calculated value of $\mathrm{F}$ is < the table value of $\mathrm{F}$.Therefore $\mathrm{Ho}$ is accepted, $\mathrm{H}_{1}$ is rejected. Thus the test has been executed using SPPS software.

\section{Group Statistics}

\begin{tabular}{|c|c|c|c|c|c|}
\hline & $\begin{array}{l}\text { PURPOSEOF } \\
\text { KINGMEMB } \\
\text { HIPINMMA }\end{array}$ & $\mathrm{N}$ & Mean & $\begin{array}{l}\text { Std. } \\
\text { Deviation }\end{array}$ & $\begin{array}{l}\text { Std. Error } \\
\text { Mean }\end{array}$ \\
\hline MMAPROGRAM & & 20 & 1.0000 & .00000 & .00000 \\
\hline $\begin{array}{l}\text { ANDACTIVITES } \\
\text { MATCHPURPOS } \\
\text { EOFTAKINGME } \\
\text { MBERSHIP }\end{array}$ & & 60 & 1.8667 & 34280 & .04426 \\
\hline
\end{tabular}


Independent Samples Test

Levene's Test
for Equality
of Variances t-test for Equality of Means

\begin{tabular}{|c|c|c|c|c|c|c|c|c|c|}
\hline & $\mathrm{F}$ & Sig. & $\mathrm{T}$ & df & $\begin{array}{l}\text { Sig. } \\
\text { (2- } \\
\text { tailed } \\
\text { ) }\end{array}$ & $\begin{array}{l}\text { Mean } \\
\text { Differ } \\
\text { ence }\end{array}$ & $\begin{array}{l}\text { Std. } \\
\text { Error } \\
\text { Differ } \\
\text { ence }\end{array}$ & $\begin{array}{l}95 \% \\
\text { Confid } \\
\text { Interva } \\
\text { the } \\
\text { Differer } \\
\text { Lowe } \\
\text { r }\end{array}$ & $\begin{array}{l}\text { idence } \\
\text { val of } \\
\text { rence } \\
\text { Upper }\end{array}$ \\
\hline $\begin{array}{l}\text { MMAPR0 Equal } \\
\text { GRAMAN variances } \\
\text { DACTIVI assumed }\end{array}$ & $\begin{array}{l}16.76 \\
0\end{array}$ & .000 & $\begin{array}{l}- \\
11 . \\
258\end{array}$ & 78 . & .000 & $\begin{array}{l}- \\
8666 \\
7\end{array}$ & $\begin{array}{l}.0769 \\
8\end{array}$ & $\begin{array}{l} \\
1.019 \\
92\end{array}$ & $\begin{array}{l}- \\
.7134 \\
1\end{array}$ \\
\hline $\begin{array}{l}\text { TESMAT Equal } \\
\text { CHPURP variances } \\
\text { OSEOFTA not } \\
\text { KINGME assumed } \\
\text { MBERSHI } \\
\text { P }\end{array}$ & & & $\begin{array}{l}- \\
19 . \\
583\end{array}$ & $\begin{array}{l}59 . \\
000\end{array}$ & .000 & $\begin{array}{l}- \\
8666 \\
7\end{array}$ & $\begin{array}{l}.0442 \\
6\end{array}$ & $\begin{array}{l}. \\
.9552 \\
2\end{array}$ & $\begin{array}{l}- \\
.7781 \\
1\end{array}$ \\
\hline
\end{tabular}

\section{RESULT:}

From the above analysis, upper and lower limit lies on the sample which researcher has chosen, hence $\mathrm{H}_{\mathrm{O}}$ accept and $\mathrm{H}_{1}$ is reject. So samples are randomly chosen. Thus the test has been executed using SPPS software.

\section{DISCUSSION AND IMPLICATIONS}

1. It is found that the majority of the members are institutional nature and the main purpose of availing membership is to improve on the skills.

2. It is found that the managerial activities of the association has been considered as effective and the time, schedule and venue is also considered as feasible by majority of the respondents.

3. The members have on major basis have agreed that their association with MMA has been helpful in improving the professional image.

4. The main and major mode of communication for any information and updates in the association with its members is e-mail, along with the SMS initiative.

5. It is found that members find the key take-away of the of MMA programmes, workshops, course and other managerial events as worthy and they could use it in the real world business scenario and thus the members are able to make an impactful growth in their professional life.

\section{LIMITATIONS}

The study is limited to the members of Madras Management Association in Chennai district and therefore findings of the study cannot be extended to other areas.

Convenient sampling has been used in the study and it has its own limitations.

Personal bias of the respondents might have crept in while answering a few questions [21]-[24]

\section{CONCLUSION}

It is reasoned that Member's bliss, which is an indication of fulfillment, is and has consistently been the most basic thing for the affiliation. Fulfillment assumes a significant job inside the affiliation's arranging with respect to doing its obligations and roles. This study has empowered the relationship to come to know the degree of fulfillment among its members and have had the option to find the neglected desires for the individuals. It has empowered the relationship to see how it manages the grumblings and inquiries of its individuals and furthermore found its part's responsiveness towards elective correspondence modes. The nature and motivation behind part's presence had been known and the viability, correspondence and advancement status of the affiliation is revealed. It has additionally made the relationship to distinguish the development in its individuals by the result of the affiliation's occasions, workshops, courses and other such administrative exercises.

\section{REFERENCES}

1. Vasanthi, S. \& Rabiyathul Basariya, S. 2019, "Influence of value analysis and cross training in industry", International Journal of Engineering and Advanced Technology, vol. 8, no. 6, pp. 1810-1811.

2. Velvizhi, R., Sri Gowtham, S. \& Jeya Priya, D. 2019, "Examination of early feedbacks for effective product retailing on E-commerce websites", International Journal of Engineering and Advanced Technology, vol. 8, no. 6 Special Issue 2, pp. 703-706.

3. Anuradha, C., Pothumani, S. \& Kavitha, R. 2019, "A novel method towards E-commerce", International Journal of Engineering and Advanced Technology, vol. 8, no. 6 Special Issue 2, pp. 535-538.

4. Thomas, J. \& Rabiyathul Basariya, S. 2019, "A study on the issues of financial ratio analysis", Indian Journal of Public Health Research and Development, vol. 10, no. 3, pp. 1079-1081

5. Ramachandran, S. \& Rabiyathul Basariya, S. 2019, "Online marketing study on customer satisfaction and relationship", Indian Journal of Public Health Research and Development, vol. 10, no. 3, pp. 1072-1078.

6. Priya, R., Vinothini, G. \& Cor Jesu, C.D. 2019, "The mentor-protégé relationship for professional growth", Journal of Advanced Research in Dynamical and Control Systems, vol. 11, no. 9 Special Issue, pp 1110-1119.

7. Jannifer Rani, N., Bina Pani, S. \& Nimisha, N.S. 2019, "A study on money back polices available in LIC", Journal of Advanced Research in Dynamical and Control Systems, vol. 11, no. 9 Special Issue, pp. 833-839.

8. Saillaja, V., Jhansi Rani, K. \& Catherine, R. 2019, "Global marketing management planning and organization", Journal of Advanced Research in Dynamical and Control Systems, vol. 11, no. 9 Special Issue, pp. 489-493.

9. Saillaja, V., Jhansi Rani, K. \& Catherine, R. 2019, "The new phase of marketing information system", Journal of Advanced Research in Dynamical and Control Systems, vol. 11, no. 9 Special Issue, pp 482-488. 
10. Thoufiqulla \& Raju, D.V. 2019, "Perception of indian investor towards investment in mutual funds with special reference to mip funds", Journal of Advanced Research in Dynamical and Control Systems, vol. 11, no. 5, pp. 177-183.

11. Jasmine, K.R.M. \& Basariya, S.R. 2018, "A study on the customers benefits on mutual funds", International Journal of Civil Engineering and Technology, vol. 9, no. 4, pp. 45-48.

12. Vasanthi, S. \& Basariya, S.R. 2019, "Pros and cons of on the job training versus off the job training", International Journal of Scientific and Technology Research, vol. 8, no. 10, pp. 671-674.

13. Pavithra, J. \& Ganesan, M. 2016, "A study on awareness and impact of micro-financial schemes", International Journal of Applied Business and Economic Research, vol. 14, no. 8, pp. 5449-5460.

14. Pavithra, J., Dilli Babu, P. \& Ambuli, T.V. 2014, "A study on budgetary control at Maruti Service Masters, Chennai", International Journal of Applied Business and Economic Research, vol. 12, no. 2, pp. 151-161.

15. Gunaraja, T.M. \& Venkatrama Raju, D. 2018, "Determining factors of organisational climate with reference to leadership styles", International Journal of Mechanical Engineering and Technology, vol. 9, no. 9, pp. 1327-1332.

16. Gunaraja, T.M. \& Venkatrama Raju, D. 2018, "The role of job satisfaction and training of employees in determining organisational climate of a selected industry", International Journal of Civil Engineering and Technology, vol. 9, no. 8, pp. 1266-1269.

17. Aarathy, T.S. \& Raju, D.V. 2018, "Performance appraisal and its effects on employees with respect to it sector in Chennai city", International Journal of Civil Engineering and Technology, vol. 9, no. 6, pp. 1535-1538.

18. Aarathy, T.S. \& Raju, D.V. 2018, "Employee perception towards performance appraisal system in IT sector", International Journal of Mechanical Engineering and Technology, vol. 9, no. 5, pp. 131-135.

19. Porselvi, W., Jublee, D. \& Sivanesan, G. 2018, "A study on factors influencing adoption of technology and innovation in banking industry, tamilnadu, India", International Journal of Mechanical Engineering and Technology, vol. 9, no. 5, pp. 789-800.

20. Akessa, G.M. and Dhufera, A.G., 2015. Factors That Influences Students Academic Performance: A Case of Rift Valley University, Jimma, Ethiopia. Journal of Education and Practice, 6(22), pp.55-63.

21. Miller, G. and Shih, C.C., 1999. A faculty assessment of the academic rigor of on-and off-campus courses in agriculture. Journal of Agricultural Education, 40, pp.57-65.

22. Tsinidou, M., Gerogiannis, V. and Fitsilis, P., 2010. Evaluation of the factors that determine quality in higher education: an empirical study. Quality Assurance in education, 18(3), pp.227-244.

23. Farooq, M.S., Chaudhry, A.H., Shafiq, M. and Berhanu, G., 2011. Factors affecting students' quality of academic performance: a case of secondary school level. Journal of quality and technology management, 7(2), pp.1-14.

24. Fitsilis, P., Gerogiannis, V. and Anthopoulos, L., 2014. Ontologies for software project management: a review. Journal of Software Engineering and Applications, 7(13), p.1096.

25. Adams, J.D. and Jaffe, A.B., 1996. Bounding the effects of R\&D: an investigation using matched establishment-firm data(No. w5544). National bureau of economic research

\section{AUTHORS PROFILE}

W. Porselvi, Assistant Professor, Department Of Science and Humanities, Bharath Institution Of Higher Education And Research Tamilnadu India

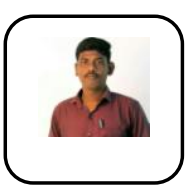

K. Thiyagarajan, Assistant Professor, Department Of Science and Humanities, Bharath Institution Of Higher Education And Research Tamilnadu India

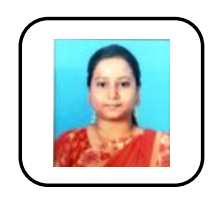

T. S. Janifer Vinnarasi Assistant Professor, Department Of Science and Humanities, Bharath Institution Of Higher Education And Research. Tamilnadu India 